\title{
Biliary Dyskinesia as a Rare Presentation of Metastatic Breast Carcinoma of the Gallbladder: A Case Report
}

\author{
A. Markelov, H. Taheri, K. Vunnamadala, and G. Ibrahim \\ Department of Surgery, Easton Hospital, 250 S 21th Street, Easton, PA 18042, USA \\ Correspondence should be addressed to A. Markelov, dr.markelov@gmail.com
}

Received 21 June 2011; Accepted 26 July 2011

Academic Editors: T. Hasebe and S. Shousha

Copyright () 2011 A. Markelov et al. This is an open access article distributed under the Creative Commons Attribution License, which permits unrestricted use, distribution, and reproduction in any medium, provided the original work is properly cited.

Background. Breast carcinoma is the most common malignancy in women worldwide. It is most commonly associated with metastases to the liver, lung, bone, and the brain. Invasive lobular carcinoma is a less common pathology with slightly higher metastases to the upper gastrointestinal tract. Invasive lobular carcinoma metastasis to the gallbladder is extremely rare. Method. In this paper we are presenting a case of a 67-year-old female with metastases of invasive lobular breast cancer to the gallbladder six years after her therapy. Conclusion. This case clearly signifies the nature of the micrometastatic foci of the invasive lobular carcinoma even many years after a successful treatment.

\section{Case Report}

A 67-year-old female was seen in the clinic complaining of a two-week history of right nipple inversion. A mass was discovered following breast examination which was biopsied-pathology revealed infiltrative lobular carcinoma. The patient subsequently underwent a right modified radical mastectomy with level three lymph node dissections. Pathological studies revealed a $7 \mathrm{~cm}$ extensive invasive lobular carcinoma with some foci of in situ ductal carcinoma. 10/16 lymph nodes were also positive. The cells were strongly estrogen receptor positive, with greater than 20\% being Ki-67 antigen positive. Staining was negative for human epidermal growth factor Receptor 2 (HER2/neu) marker. The patient successfully finished her chemotherapy and radiation treatments with continuous aromatase inhibitor therapy. Six years later, she developed symptoms of nausea accompanying a 20-pound weight loss over a period of two months. Subsequent workup with Hepatobiliary Iminodiacetic Acid scan revealed gallbladder dyskinesia. The patient underwent an uncomplicated laparoscopic cholecystectomy. Cytological examination of the gallbladder was significant for findings of foci of tumor with a single file arrangement present outside the muscularis propria and some tumor cells within the muscularis propria. There were estrogen and progesterone positive receptors with more than $10 \% \mathrm{Ki}$ 67 antigen positive and HER2/neu negative marker. These findings were significant for metastatic lobular carcinoma of the breast.

\section{Discussion}

There is well-known evidence of breast cancer's metastatic potential with contiguous, lymphatic, and hematogenous spread. Common sites of metastasis include bone, lungs, and the liver $[1,2]$. The central nervous system (CNS), endocrine organs (ovary, adrenal, pituitary), pericardium, abdominal cavity, and eye are infrequently involved organs [1]. Breast carcinoma metastasizing to the gallbladder is extremely rare and infrequently described. In one large autopsy series, metastases to the gallbladder were found only in $5.8 \%$ of cancer patients [3]. The tumor which is most likely to metastasize to the gallbladder is malignant melanoma (Figure 1) [4].

Metastatic breast carcinoma involving the gallbladder or biliary tract presents with abdominal pain, symptoms of cholecystitis and obstructive jaundice [5-7]. Crawford et al. [8] reported a 73-year-old lady with breast carcinoma who developed cholecystitis and subsequently underwent 
TABLE 1: Feature of cases with metastases of breast carcinoma to gallbladder.

\begin{tabular}{|c|c|c|c|c|c|}
\hline Reference & Type of breast cancer & Presentation & Diagnosis & Treatment & Outcome \\
\hline Boari et al. & $\begin{array}{l}\text { Invasive lobular } \\
\text { carcinoma } \\
\text { Invasive ductal } \\
\text { carcinoma }\end{array}$ & $\begin{array}{l}\text { RUQ pain, acute } \\
\text { cholecystitis }\end{array}$ & $\begin{array}{l}\text { RUQ US showed } \\
\text { gallbladder mass and } \\
\text { stones } \\
\text { Carcinoma confirmed } \\
\text { by pathology }\end{array}$ & $\begin{array}{l}\text { Laparoscopic } \\
\text { cholecystectomy }\end{array}$ & Cured \\
\hline Zagouri et al. & $\begin{array}{l}\text { Invasive lobular } \\
\text { carcinoma grade II } \\
\text { Invasive ductal } \\
\text { carcinoma grade I }\end{array}$ & $\begin{array}{l}\text { Intermittent RUQ } \\
\text { pain }\end{array}$ & $\begin{array}{l}\text { RUQ US showed } \\
\text { stones } \\
\text { Carcinoma confirmed } \\
\text { by pathology }\end{array}$ & $\begin{array}{l}\text { Laparoscopic } \\
\text { cholecystectomy }\end{array}$ & Cured \\
\hline Shah et al. & Not specified & Altered mental status & $\begin{array}{l}\text { RUQ US, CT } \\
\text { abdomen, } \\
\text { paracentesis }\end{array}$ & $\begin{array}{l}\text { Exploratory } \\
\text { laparotomy }\end{array}$ & $\begin{array}{l}\text { Expired POD } \\
\text { no. } 5\end{array}$ \\
\hline \multirow[t]{2}{*}{ Crawford et al. } & $\begin{array}{l}\text { Infiltrating ductal } \\
\text { carcinoma }\end{array}$ & $\begin{array}{l}\text { Upper abdominal } \\
\text { pain with nausea for } 3 \\
\text { weeks }\end{array}$ & $\begin{array}{l}\text { SBFT, RUQ US, oral } \\
\text { cholecystogram }\end{array}$ & $\begin{array}{l}\text { Laparoscopic } \\
\text { cholecystectomy } \\
\text { converted to open }\end{array}$ & $\begin{array}{l}\text { One year s/p } \\
\text { cholecystectomy }\end{array}$ \\
\hline & $\begin{array}{l}\text { Infiltrating lobular } \\
\text { carcinoma }\end{array}$ & $\begin{array}{l}\text { Upper abdominal } \\
\text { postprandial pain for } \\
6 \text { months }\end{array}$ & $\begin{array}{l}\text { RUQ US, oral } \\
\text { cholecystogram, } \\
\text { HIDA scan } \\
\text { Carcinoma confirmed } \\
\text { by pathology }\end{array}$ & $\begin{array}{l}\text { Laparoscopic } \\
\text { cholecystectomy } \\
\text { converted to open }\end{array}$ & $\begin{array}{l}\text { Expired } 3 \text { years } \\
\text { later from } \\
\text { disseminated } \\
\text { metastases }\end{array}$ \\
\hline Beaver et al. & Not specified & $\begin{array}{l}\text { RUQ pain, nausea } \\
\text { and vomiting (acute } \\
\text { cholecystitis) }\end{array}$ & $\begin{array}{l}\text { RUQ US Carcinoma } \\
\text { confirmed by } \\
\text { pathology }\end{array}$ & $\begin{array}{l}\text { Cholecystectomy } \\
\text { combined with } \\
\text { chemotherapy (5FU, } \\
\text { methotrexate, } \\
\text { vincristine) }\end{array}$ & Cured \\
\hline Case report & $\begin{array}{l}\text { Invasive lobular } \\
\text { carcinoma with foci } \\
\text { of DCIS }\end{array}$ & $\begin{array}{l}\text { Nausea and weight } \\
\text { loss for } 2 \text { months }\end{array}$ & $\begin{array}{l}\text { HIDA scan showed } \\
\text { biliary dyskinesia } \\
\text { Carcinoma confirmed } \\
\text { by pathology }\end{array}$ & $\begin{array}{l}\text { Laparoscopic } \\
\text { cholecystectomy }\end{array}$ & Cured \\
\hline
\end{tabular}

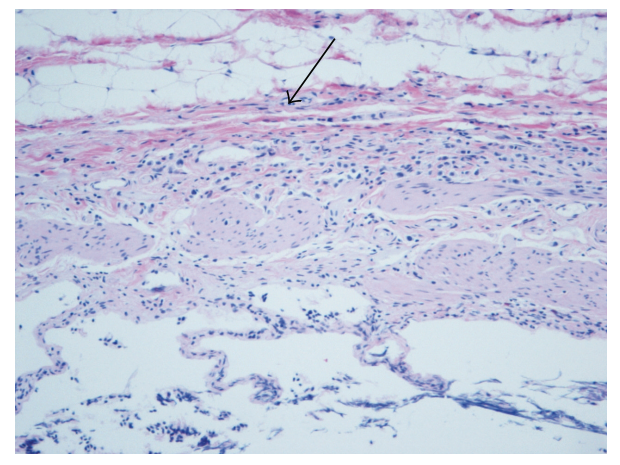

FIGURE 1: Invasion of the muscularis propria of the gallbladder by metastatic lobular carcinoma of the breast.

cholecystectomy. The result of pathological examination was consistent with metastatic carcinoma from primary breast carcinoma. Similarly, Ferlicot et al. [9] reported two cases of metastatic breast cancer presenting as cholecystitis. Both patients had undergone mastectomy years earlier. Pathologic evaluation of the gallbladder specimen revealed metastatic infiltrating ductal carcinoma in one patient and infiltrating lobular carcinoma in the other (Figure 2 and Table 1) [9].

In our patient, we saw that the lobular carcinoma was accompanied by metastatic spread. Lobular carcinomas

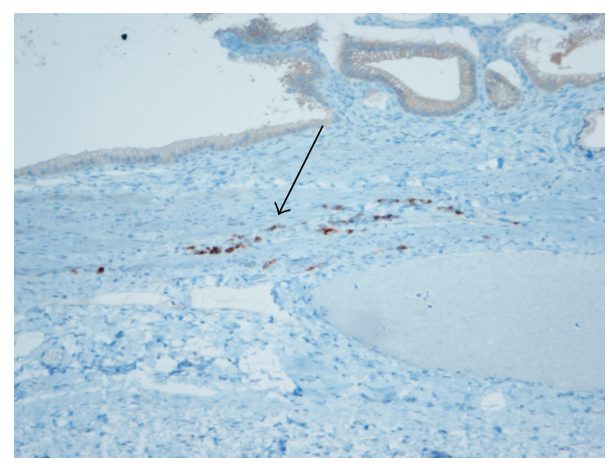

FIGURE 2: Estrogen positive cells in gallbladder wall on immunohistochemical staining.

show a preference to gynecologic organs, peritoneumretroperitoneum, and gastrointestinal system, including the gallbladder [10].

\section{Conclusion}

This is an extremely rare case of invasive lobular carcinoma with metastases to the gallbladder. This case clearly signifies the importance of the micrometastatic foci of the invasive lobular carcinoma many years after a successful treatment. 


\section{References}

[1] B. L. Beaver, D. A. Denning, and J. P. Minton, "Metastatic breast carcinoma of the gallbladder," Journal of Surgical Oncology, vol. 31, no. 4, pp. 240-242, 1986.

[2] C. D. Scopa, C. Aletra, B. Lifschitz-Mercer, and B. Czernobilsky, "Metastases of breast carcinoma to the uterus. Report of two cases, one harboring a primary endometrioid carcinoma, with review of the literature," Gynecologic Oncology, vol. 96, no. 2, pp. 543-547, 2005.

[3] H. L. Abrahms, R. Spiro, and N. Goldstein, "Metastases in carcinoma; analysis of 1000 autopsied cases," Cancer, vol. 3, no. 1, pp. 74-85, 1950.

[4] R. G. B. Langley, E. M. Bailey, and A. J. Sober, "Acute cholecystitis from metastatic melanoma to the gall-bladder in a patient with a low-risk melanoma," British Journal of Dermatology, vol. 136, no. 2, pp. 279-282, 1997.

[5] R. J. Shah, A. Koehler, and J. D. Long, "Bile peritonitis secondary to breast cancer metastatic to the gallbladder," American Journal of Gastroenterology, vol. 95, no. 5, pp. 13791381, 2000.

[6] J. S. Park, Y. S. Chae, S. J. Hong, D. H. Shin, J. S. Choi, and B. R. Kim, "Metastatic renal cell carcinoma of the gallbladder," Yonsei Medical Journal, vol. 44, no. 2, pp. 355-358, 2003.

[7] M. S. Rabin and I. A. Richter, "Metastatic breast carcinoma presenting as obstructive jaundice. A report of 3 cases," South African Medical Journal, vol. 55, no. 10, pp. 388-390, 1979.

[8] D. L. Crawford, I. T. Yeh, and J. T. Moore, "Metastatic breast carcinoma presenting as cholecystitis," American Surgeon, vol. 62, no. 9, pp. 745-747, 1996.

[9] S. Ferlicot, A. Vincent-Salomon, J. Médioni et al., "Wide metastatic spreading in infiltrating lobular carcinoma of the breast," European Journal of Cancer, vol. 40, no. 3, pp. 336-341, 2004.

[10] M. J. Borst, J. A. Ingold, P. O. Hasselgren et al., "Metastatic patterns of invasive lobular versus invasive ductal carcinoma of the breast," Surgery, vol. 114, no. 4, pp. 637-642, 1993. 


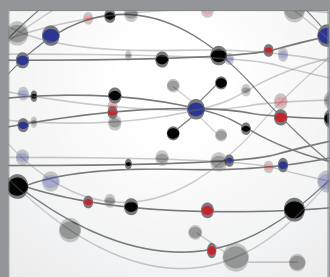

The Scientific World Journal
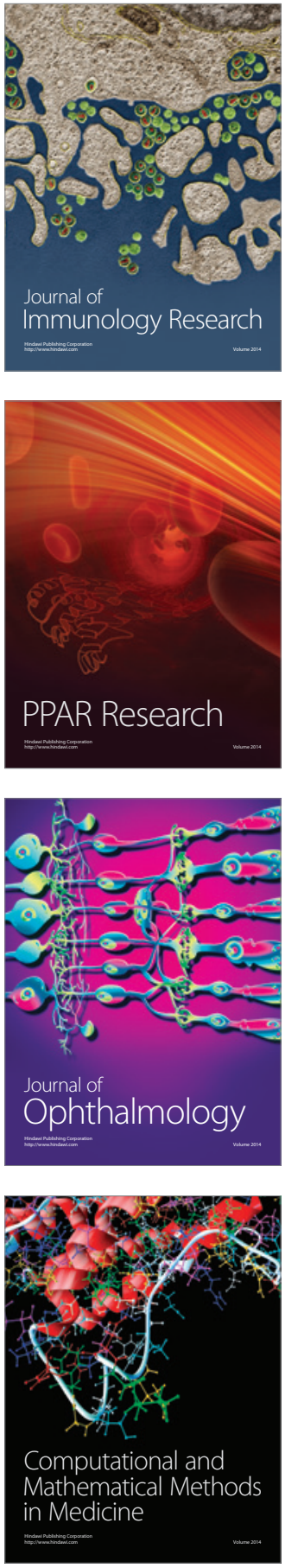

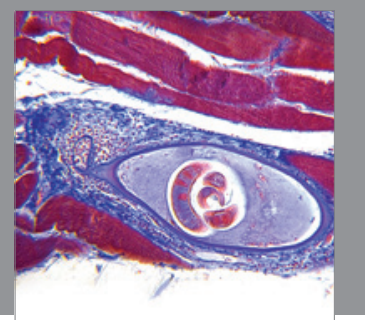

Gastroenterology

Research and Practice
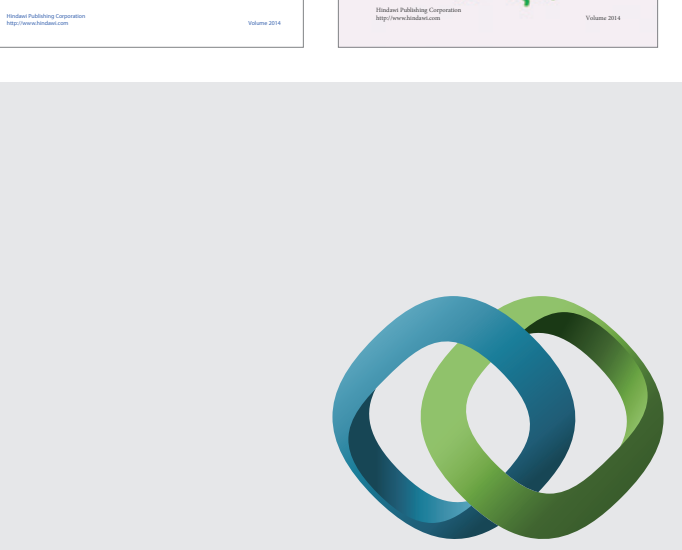

\section{Hindawi}

Submit your manuscripts at

http://www.hindawi.com
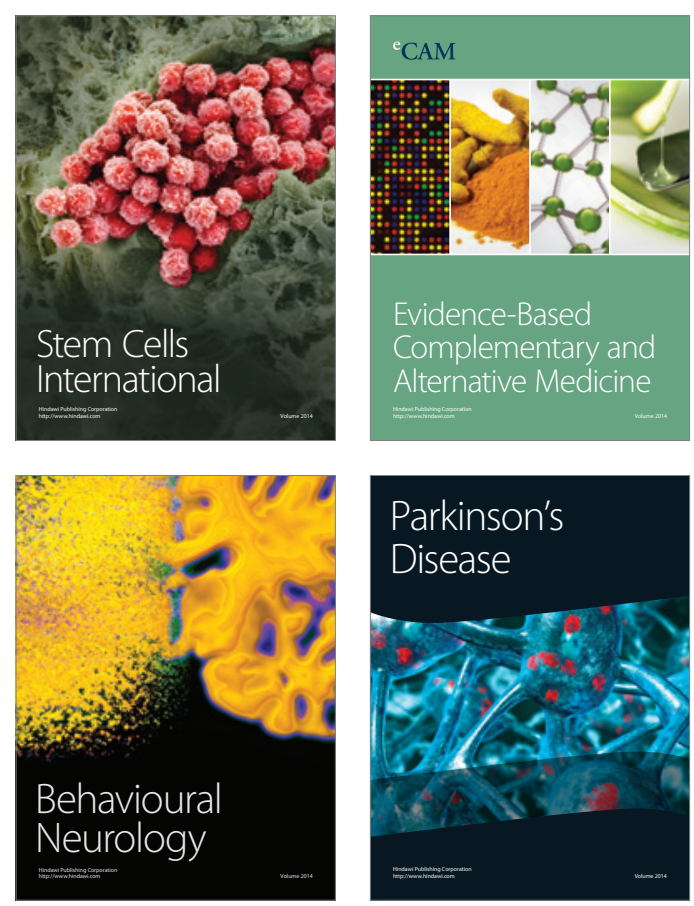

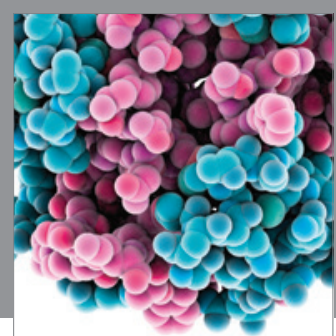

Journal of
Diabetes Research

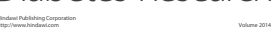

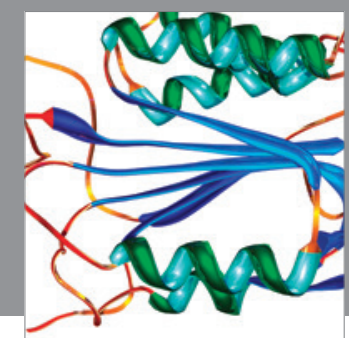

Disease Markers
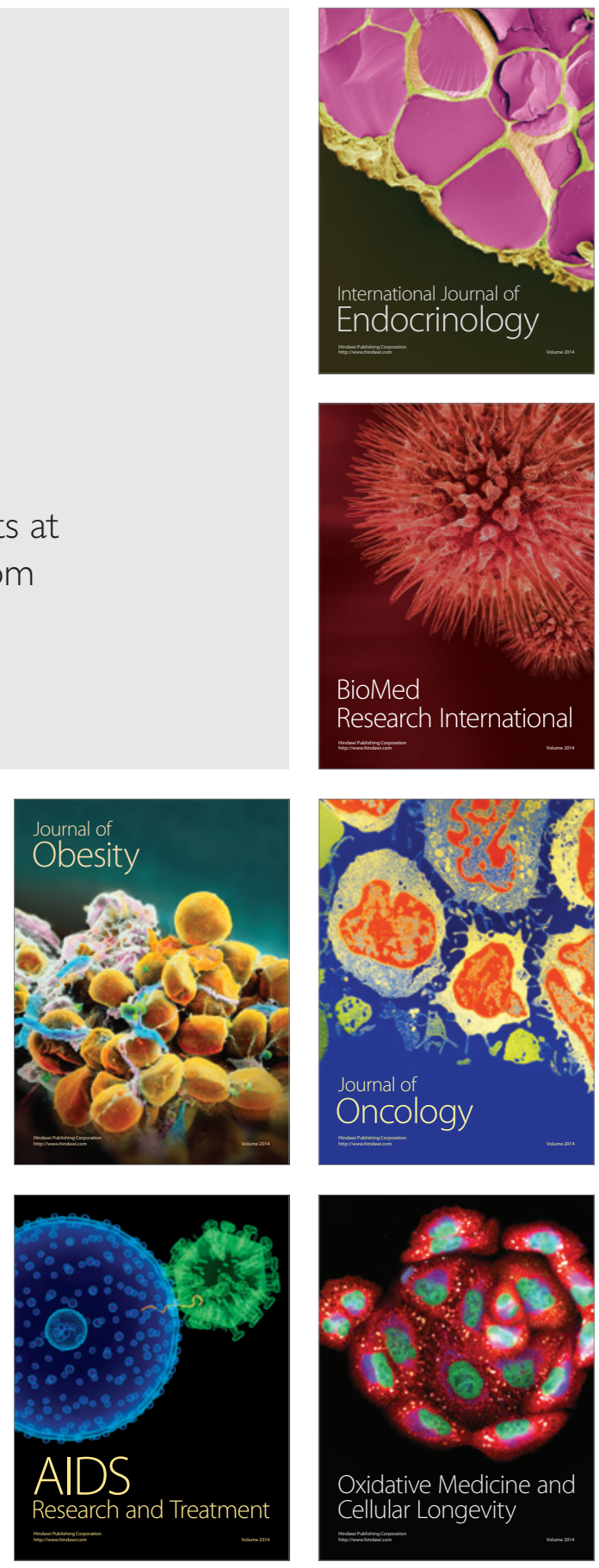